\title{
Studi Karakterisasi Sampah Landfill dan Potensi Pemanfaatannya (Studi Kasus di TPA Sukawinatan dan Bantargebang)
}

\section{Study of Characterization of Landfill Based Municipal Solid Waste and Its Potential Utilization (Case Study at Sukawinatan and Bantargebang Landfill)}

\author{
SRI WAHYONO, FIRMAN L. SAHWAN, FEDDY SURYANTO, IRHAN FEBRIYANTO, RUDI NUGROHO, \\ MUHAMMAD HANIF
}

\author{
Pusat Teknologi Lingkungan, Badan Pengkajian dan Penerapan Teknologi \\ Gedung 820 Geostech, Kawasan Puspiptek Serpong, Tangerang Selatan, Provinsi Banten, 15314 \\ Email: sri.wahyono@bppt.go.id
}

\begin{abstract}
Landfills contain materials that can be recovered to be recycled or used as an energy source. The purpose of this study is to conduct waste characterization that has long been buried in landfill which includes analysis of composition, proximate analysis, and ultimate analysis. Then the waste is analyzed for its use as recycled material and energy sources. The study was conducted at the Sukawinatan landfill (Palembang) and the Bantargebang landfill (Bekasi). Sampling was carried out on garbage that had been buried in landfills by digging at depths of up to $5 \mathrm{~m}$ using an excavator. Furthermore, the samples are dried in the sun, sifted with rotary screen, and sorted manually. Some samples were taken by quartering to be analyzed in the laboratory. The results of the research and analysis showed that (i) landfill waste was dominated by compost material (31-47\%) and plastic combustible material (32-43\%) and nonplastic combustible material (32-43\%); (ii) shaped material such as compost has the potential as a substitute for landfill cover and as soil conditioner; (iii) potentially recycled materials such as plastic waste need intensive sorting and cleaning; (iv) landfills excavated waste can be potentially used as an energy source or refuse-derifed fuels (RDF) with a heating value between 7.31-15.61 MJ / kg; (v) landfills excavated waste has the potential to be used as fuel for incinerators; (vi) utilization of landfill waste for the cement industry still faces several obstacles such as high chlorine content and water content.
\end{abstract}

Keywords: landfill, waste characterization, composition, proximate, ultimate

\begin{abstract}
ABSTRAK
TPA mengandung material yang dapat diambil untuk didaur ulang atau dimanfaatkan sebagai sumber energi. Tujuan dari penelitian ini adalah untuk melakukan karakterisasi sampah yang telah lama tertimbun di TPA yang meliputi analisis komposisi, analisis proksimat, dan analisis ultimat. Kemudian sampah tersebut dilakukan analisis pemanfaatannya sebagai bahan daur ulang dan sumber energi. Penelitian dilakukan di TPA Sukawinatan (Palembang) dan di TPA Bantargebang (Bekasi). Pengambilan sampel dilakukan terhadap sampah yang sudah tertimbun di landfill dengan cara menggali pada kedalaman hingga $5 \mathrm{~m}$ menggunakan excavator. Selanjutnya sampel dijemur, diayak dengan penyaring berputar (rotary screen), dan dipilah secara manual. Sebagian sampel diambil dengan metode perempatan (quartering) untuk kemudian dianalisa di laboratorium. Hasil dari penelitian dan analisisnya memperlihatkan bahwa (i) sampah galian TPA didominasi oleh material kompos (31-47\%) dan material combustible plastik (32-43\%) serta combustible nonplastik (3243\%); (ii) material berbentuk seperti kompos memiliki potensi sebagai pengganti soil cover TPA dan sebagai material pembenah tanah (soil conditioner); (iii) material yang potensial didaur ulang seperti sampah plastik perlu pemilahan dan pembersihan yang intensif; (iv) sampah galian TPA potensial dimanfaatkan sebagai sumber energi atau RDF (refuse-derifed fuels) dengan nilai kalor antara 7,31-15,61 MJ/kg; (v) sampah galian TPA berpotensi digunakan sebagai bahan bakar insinerator PLTSa; (vi) pemanfaatan sampah galian TPA untuk industri semen masih menghadapi beberapa kendala seperti tingginya kandungan klorin dan kadar air.
\end{abstract}

Kata kunci: landfill, karakterisasi sampah, komposisi, proksimat, ultimat 


\section{PENDAHULUAN}

Landfill mining adalah ekskavasi dan pemindahan material dari tempat pemrosesan akhir sampah (TPA) untuk tujuan daur ulang dan pengomposan ${ }^{(1)}$. Landfill mining bertujuan merehabilitasi lahan TPA sebagai upaya penanganan pencemaran pasca penutupan TPA ${ }^{(2,3)}$. Melalui penambangan (mining), TPA ditransformasi menjadi tempat penampungan sampah temporer(4). Dengan demikian, konsep landfill mining memungkinkan lokasi TPA dapat digunakan secara berulang-ulang.

Dalam sistem yang terintegrasi, landfill mining memerlukan berbagai aspek pendukung agar bisa dilaksanakan dengan baik seperti aspek teknologi, regulasi dan pemasaran. Ketiga aspek tersebut menentukan performansi ekonomi dan keberlanjutan landfill mining. Aspek teknologi meliputi dua hal pokok yaitu teknologi untuk merecovery material dan me-recovery energi. Aspek regulasi antara lain meliputi perijinan, subsidi, pajak, dan sebagainya. Sementara itu, aspek pemasaran meliputi kebutuhan pasar, harga material, biaya input, dan energi(5).

Operasi landfill mining tergantung dari parameter instrinsik dan ekstrinsik landfill. Yang dimaksud dengan parameter intrinsik adalah kondisi internal landfill seperti luas, lokasi, umur, tipe, dan komposisi sampahnya. Sementara itu, parameter ekstrinsik adalah kondisi eksternal seperti ketersediaan teknologi yang cocok, batasan ekonomi dan kondisi sosial(6). Kedua parameter tersebut saling mempengaruhi dan sama pentingnya.

Dalam landfill mining, material yang diekskavasi kemudian dipilah dengan tujuan untuk memisahkan material menurut ukuran dan jenisnya. Pemilahan dilakukan secara bertahap sehingga didapatkan material yang dapat didaur ulang (recyclable materials) seperti material logam besi dan non besi, plastik, kaca, dan sebagainya. Material tersebut merupakan sumberdaya sekunder yang bermanfaat untuk mensubstitusi sumber daya primer. Hal tersebut dikenal sebagai konsep "limbah menjadi materi" (waste to material).

Sementara itu, secara konsep, material lainnya yang tidak dapat langsung dimanfaatkan sebagai sumberdaya sekunder diproses lebih lanjut dengan teknologi transfomasi. Dari proses ini akan didapatkan material siap di daur ulang, siap dikonversikan secara termal menjadi energi (waste to energy), kompos, dan residu material yang secara teknis saat ini belum bisa di-recovery atau kelayakan ekonominya belum sesuai dengan yang diharapkan.
Penggunaan kembali TPA merupakan opsi penting bagi solusi permasalahan langkanya lahan untuk TPA baru di perkotaan. Dalam upaya menggunakan kembali lahan TPA, kegiatan landfill mining merupakan kegiatan inti yang melibatkan integrasi sistem teknologi, sosial, dan lingkungan. Landfill mining selain penting dalam keberlanjutan pengelolaan sampah, juga sangat penting dalam kerangka efisiensi sumber daya yakni dalam recovery material dan energi. Informasi tentang komposisi material sampah dan nilai kalornya sangat bermanfaat dalam upaya pemanfaatan sampah menjadi material untuk didaur ulang dan energi.

Dalam ekskavasi material TPA yang merupakan salah satu proses dalam landfill mining dilakukan dengan memobilisasi alat berat seperti excavator, rotary screen, wheel loader, dan truk. Selanjutnya material ekskavasi dipilah berdasarkan ukuran fraksinya. Menurut Hoogland (2011), ukuran lubang saringan mempunyai hubungan erat dengan komposisi dan karakteristik material sampah $^{(1)}$.

Tujuan dari penelitian ini adalah untuk melakukan karakterisasi sampah yang telah lama tertimbun di TPA mulai dari analisis komposisi, analisis proksimat hingga analisis ultimat dan kemudian menganalisis potensi pemanfaatannya sebagai bahan baku daur ulang dan sumber energi.

\section{METODOLOGI PENELITIAN}

Penelitian dilakukan di dua TPA dalam waktu yang berbeda yaitu di Zona A TPA Sukawinatan (Palembang) yang dilakukan pada Bulan Oktober 2015 dan di TPA Bantargebang (Bekasi) pada Oktober 2018.

Di TPA Sukawinatan, sampel diambil dari dua lokasi pada bagian TPA yang telah ditutup pengoperasiannya dan umurnya sekitar 10 tahun. Dari kedua lokasi tersebut, sampel diambil dengan cara menggalinya dengan excavator pada kedalaman 0-1 m, 2-3 m dan 4-5 m. Pada setiap kedalaman tersebut diambil sampel sekitar $1,5 \mathrm{~m}^{3}$, dan kemudian diukur berat dan volumenya. Sampel yang berasal dari tiga kedalaman yang berbeda tersebut diambil sebagian $(2 \mathrm{~kg})$ secara random untuk dikirim ke laboratorium untuk dianalisis kadar airnya.

Sampel lainnya dari masing-masing lokasi, kemudian dicampur dan dijemur di bawah sinar matahari selama 3 jam di atas TPA. Sampel yang telah dijemur, kemudian diambil sekitar $300 \mathrm{~kg}$ melalui metode perempatan (quartering) secara bertahap. Masing-masing sampel dari kedua lokasi 
tersebut kemudian disaring dengan penyaring berputar (rotary screen) yang lubang-lubangnya berukuran $10 \mathrm{~mm}$. Material yang lolos saringan diukur berat dan volumenya. Material yang tidak lolos saringan kemudian dipilah secara manual dan dikelompokan menjadi 3 jenis yaitu, (i) sampah yang dapat dibakar (combustible) plastik; (iii) combustible non-plastik; dan (iii) sampah lainnya. Dari setiap jenis material tersebut diukur berat dan volumenya dan masing-masing diambil $2 \mathrm{~kg}$ untuk kemudian dikirim ke laboratorium untuk dianalisis proksimatnya (kadar air, kadar abu, volatile matter, dan nilai kalornya).

Di TPA Bantargebang, sampel diambil dari lokasi pembangunan pilot project PLTSa yang digali hingga kedalaman $5 \mathrm{~m}$. Lokasi tersebut adalah tempat penimbunan sampah yang memiliki umur lebih dari 10 tahun. Material galian sampah tersebut kemudian ditimbun di tempat terbuka. Dari gunungan sampah tersebut kemudian diambil secara random sampah sebanyak $350 \mathrm{~kg}$. Sampah tersebut kemudian disaring dengan rotary screen. Sampah yang telah disaring selanjutnya dipilah secara manual menjadi beberapa jenis sampah (sampah plastik, kayu, kain, karet/kulit, logam, kaca, dan lainnya). Sampah yang telah terpilah diukur berat dan volumenya. Kemudian dari sampah galian TPA Bantargebang juga diambil sekitar $100 \mathrm{~kg}$ dan dengan metode quartering diambil $2 \mathrm{~kg}$ sampel untuk analisis proksimat untuk menentukan kadar air, kadar abu, volatile matter, fixed carbon dan nilai kalornya dan analisis ultimat untuk menentukan kadar $\mathrm{C}, \mathrm{H}, \mathrm{O}, \mathrm{N}, \mathrm{S}$, dan $\mathrm{Cl}$.

\section{HASIL DAN PEMBAHASAN}

\subsection{Proses Penelitian Melalui Metode Landfill Mining}

Rangkaian kegiatan penelitian ini meliputi proses yang diawali dengan proses ekskavasi material sampah, kemudian dilanjutkan dengan penjemuran, penyaringan, dan pemilahan sampah.

Kegiatan ekskavasi dilakukan pada bagian lokasi TPA Sukawinatan dan TPA Bantargebang yang umurnya telah lama (lebih dari 10 tahun) dan tidak dioperasikan lagi untuk menghindari bahaya ekspos landfill gas yang berbau dan dapat menimbulkan ledakan. Ekskavasi sampah di TPA Sukawinatan dilakukan pada tiga level kedalaman TPA (0-1 m; 2-3 m; dan 4-5 m) dilakukan dengan menggalinya menggunakan bantuan alat berat excavator. Sementara itu, ekskavasi sampah di TPA Bantargebang juga dilakukan sampai kedalaman 5 meter, namun hasil ekskavasi tidak dikelompokan berdasarkan level kedalamannya.

Proses ekskavasi sampah di TPA Sukawinatan dan TPA Bantargebang dilakukan pada saat musim kemarau. Seandainya proses ekskavasi dilakukan pada musim hujan, maka proses ekskavasi sampah kemungkinan akan terganggu karena sampah yang digali akan basah dan timbul genangan air di permukaan area ekskavasi yang akan mengganggu kegiatan mining.

Hasil galian sampah kemudian digelar dan dijemur di atas terpal dipermukaan TPA di bawah sinar matahari selama sekitar 3 jam untuk mengurangi kadar air sampah. Sementara itu hasil galian sampah dari TPA Bantargebang disimpan hingga sekitar 4 bulan di atas TPA.

Material yang telah dijemur atau disimpan kemudian disaring dengan alat rotary screen untuk memisahkan material berukuran lebih kecil dari 10 $\mathrm{mm}$. Material kecil berukuran dibawah $10 \mathrm{~mm}$ lolos melalui saringan, sedangkan material yang memiliki ukuran di atas $10 \mathrm{~mm}$ tidak lolos saringan. Selanjutnya, material yang tidak lolos saringan dipilah secara manual sesuai dengan jenisnya yaitu sampah plastik, kayu, kain, karet, kaca, logam, sisa bongkaran bangunan, dan sebagainya.

Untuk keperluan pemanfaatan sampah sebagai sumber energi, material terpilah tersebut dikelompokan menjadi sampah yang dapat terbakar (combustible) baik yang berasal dari material plastik maupun non-plastik (kayu, kain, karet, dan kulit), serta material tidak/sulit terbakar (uncombustible) seperti kaca, logam, batu, keramik, dan sebagainya. 


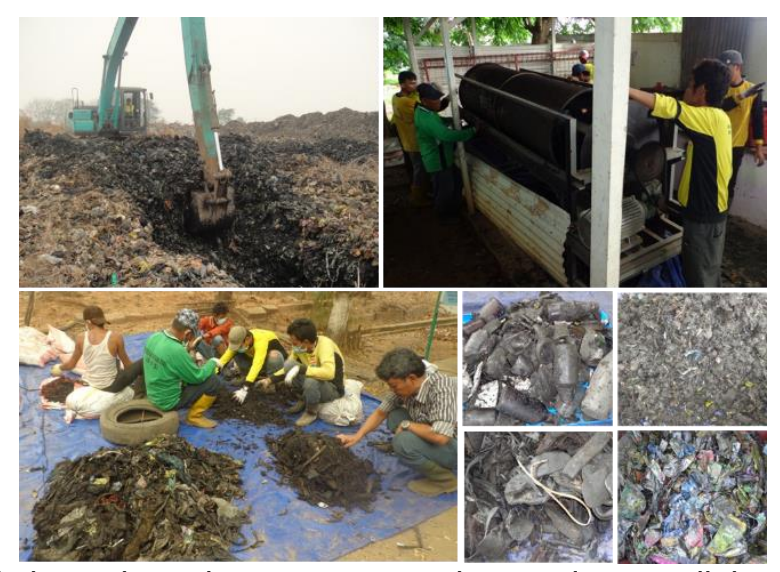

Gambar 1. Proses ekskavasi, penjemuran, penyaringan, dan pemilahan sampah galian TPA

\subsection{Pengaruh Penjemuran dan Penyimpanan Sampah Galian TPA}

Tabel 1 memperlihatkan bahwa di TPA Sukawinatan, semakin dalam posisi sampah, baik di lokasi pertama maupun lokasi kedua, berat jenis sampah semakin besar. Sebagai contoh, di lokasi kedua, pada kedalaman 0-1 m, 2-3 m, dan 4-5 m secara berturut-turut berat jenisnya meningkat dari 0,33 ; 0,46; hingga 0,57 . Sampah dari posisi yang semakin, secara visual kelihatan semakin berwarna gelap dan semakin lembap.

Berat jenis rerata dari ketiga kedalaman tersebut, adalah 0,44 (dari lokasi pertama) dan 0,45 (dari lokasi kedua). Dibandingkan dengan penelitian serupa di luar negeri, di TPA Halbenrain, Austria, berat jenis sampah di TPA Sukawinatan relatif tinggi. Di TPA Halbenrain, berat jenis sampah galian (dari kedalaman $6 \mathrm{~m}$ ) nilainya hanya $0,25^{(7)}$. Perbedaan tersebut dapat dipengaruhi oleh karakteristik sampah yang dibuang ke TPA, jenis TPA yang dioperasikan, dan perbedaan iklim. Tipe TPA Sukawinatan adalah open dumping yang dipengaruhi oleh iklim tropik dengan dua musim (musim hujan dan kemarau), sedangkan TPA Halbenrain adalah sanitary landfill yang berada di iklim temperata dengan empat musim (musim dingin, semi, panas dan gugur).

Kadar air sampah galian TPA Sukawinatan relatif tinggi yaitu 69,23\% (lokasi 1) dan 68,39\% (lokasi 2). Oleh karena kadar airnya yang tinggi, pengurangan kelembapan perlu dilakukan untuk mempermudah proses lanjutan yaitu proses pemisahan sampah.

Setelah dijemur selama 3 jam, kadar air sampah turun dari $69,23 \%$ menjadi 50,57 $65,63 \%$ (pada lokasi 1) dan dari 68,38\% menjadi 25,18 - 65,93\% (pada lokasi 2). Penurunan kadar air tersebut juga ditunjukkan dengan menurunnya berat jenis sampah dari 0,44 menjadi 0,34 (pada lokasi 1) dan dari 0,45 menjadi 0,31 (pada lokasi 2). Sementara itu, kadar air sampah TPA Bantargebang pasca penyimpanan adalah $31,8 \%$ dengan berat jenis 0,36 . Hal tersebut dapat dilihat pada Tabel 1.

Turunnya kadar air dan berat jenis sampah setelah dijemur atau disimpan mengindikasikan adalanya proses pengeringan.

Tabel 1. Berat jenis dan kadar air sampah galian TPA Sukawinatan

\begin{tabular}{|c|c|c|c|c|}
\hline \multirow[t]{2}{*}{ Berat Jenis } & \multicolumn{3}{|c|}{$\begin{array}{c}\begin{array}{c}\text { Sebelum } \\
\text { Penjemuran }\end{array} \\
\text { Kedalaman } \\
\end{array}$} & \multirow[t]{2}{*}{$\begin{array}{c}\text { Setelah } \\
\text { Penjemuran }\end{array}$} \\
\hline & $0-1 \mathrm{~m}$ & $2-3 \mathrm{~m}$ & $4-5 \mathrm{~m}$ & \\
\hline \multicolumn{5}{|c|}{ Lokasi 1} \\
\hline Berat Jenis & 0,43 & 0,43 & 0,45 & 0,34 \\
\hline Berat Jenis (rerata) & \multicolumn{3}{|c|}{0,44} & \\
\hline Kadar Air (\%) & \multicolumn{3}{|c|}{69,23} & $50,67-65,63$ \\
\hline \multicolumn{5}{|c|}{ Lokasi 2} \\
\hline Berat Jenis & 0,33 & 0,46 & 0,57 & 0,31 \\
\hline Berat Jenis (rerata) & \multicolumn{3}{|c|}{0,45} & \\
\hline Kadar Air (\%) & \multicolumn{3}{|c|}{68,39} & $25,18-65,93$ \\
\hline
\end{tabular}




\subsection{Komposisi Sampah Galian TPA dan Potensi Recovery Material}

Pasca proses penjemuran atau penyimpanan, sampah kemudian disaring. Pemisahan sampah dengan alat penyaring rotary screen memisahkan material berukuran di bawah dan di atas $10 \mathrm{~mm}$. Material yang yang lolos saringan (fraksi dengan ukuran di bawah $10 \mathrm{~mm}$ ) berupa material seperti tanah/kompos. Sementara itu, material yang tidak lolos saringan (fraksi dengan ukuran lebih dari 10 $\mathrm{mm}$ ) berupa material plastik, kain, kaca, karet, batu, dan sebagainya.

\subsubsection{Material Kompos}

Dari penyaringan sampah yang digali dari TPA Sukawinatan dan TPA Bantargebang didapatkan material seperti tanah atau kompos yang jumlahnya relatif banyak. Untuk pembahasan selanjutnya, material tersebut disebut sebagai kompos. Dari TPA Batargebang didapatkan material kompos sebanyak $31 \%$ seperti yang dapat dilihat pada Gambar 2. Sementara itu, dari TPA Sukawinatan, didapatkan material kompos sebanyak $47 \%$. Hasil serupa juga didapatkan dari beberapa penelitian lain. Penelitian Lopes et al. (2017) di TPA Halbenrain, Austria, menunjukkan fraksi serupa sebesar $49,5 \%(7)$, sedangkan penelitian Frandegard et al. (2013) di beberapa TPA di Swedia menunjukan komposisi fraksi serupa sebesar $56,3 \%{ }^{(8)}$. Pada penelitian lainnya, dari identifikasi terhadap enam studi kasus yang dilakukan oleh Pastre, G. et al. (2017) didapatkan informasi bahwa komposisi fraksi serupa sebesar $45,9 \%(9)$.

Besarnya kandungan material kompos dari hasil galian TPA kemungkinan disebabkan oleh banyaknya sampah organik yang masuk ke TPA dan intensitas pelapisan tanah pada saat operasi timbunan sampah di TPA.

Melalui proses penyaringan, sebagian material kompos yang di dalamnya mengandung tanah, pasir dan fraksi kecil lainnya masih menempel pada material yang tidak lolos saringan.

Material kompos dari TPA Sukawinatan memiliki berat jenis 1,24 dengan kondisinya yang relatif lembab, sedangkan kompos dari TPA Bantargebang berat jenisnya 0,66. Material kompos dari TPA merupakan material yang dapat digunakan kembali di TPA sebagai pengganti soil cover atau dimanfaatkan sebagai pembenah tanah (soil conditioner) pada pemupukan tanaman (nontanaman pangan), rehabilitasi lahan kritis, dan rehabilitasi lahan bekas pertambangan.

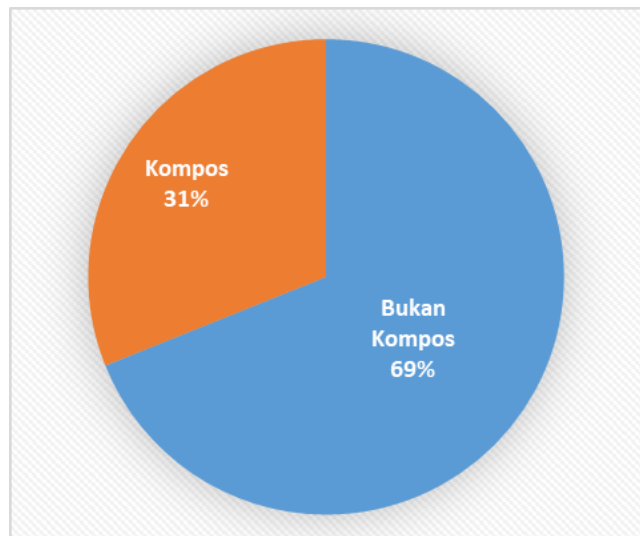

Gambar 2. Komposisi kompos dari sampah TPA Bantargebang

\subsubsection{Material Potensial Daur Ulang}

Selanjutnya, material lain yang tidak lolos saringan, memiliki kandungan jenis sampah yang beragam. Melalui proses pemilahan manual, dari sampah galian TPA Bantargebang didapatkan material plastik (sebanyak 46\%), kayu bekas $(20 \%)$, kain $(11 \%)$, karet/kulit $(7 \%)$, logam (1\%), kaca $(1 \%)$ dan material lainnya seperti batu, keramik, dan sebagainya (14\%). Hal tersebut dapat dilihat pada Gambar 3.

Material seperti plastik, karet, logam dan kaca memiliki potensi untuk di-recovery menjadi bahan baku sekunder pada industri daur ulang. Namun nilai potensinya menjadi rendah karena masih tercampur dengan material pengotor (impurities) yang menempel seperti kompos, tanah, pasir dan sebagainya. Zhou et al. (2014), dalam penelitiannya terhadap sampah galian TPA di Tiongkok, menyebutkan bahwa kandungan pengotor dalam sampah plastik mencapai $71 \%\left({ }^{(10)}\right.$. Pengotor tersebut secara normal sulit dibersihkan karena menempel kuat di permukaan plastik. Proses pembersihan kotoran atau pencucian memerlukan biaya operasi yang diperkirakan tinggi sehingga akan membebani biaya daur ulang. Dalam kondisi tersebut, kegiatan daur ulang dapat menjadi tidak ekonomis.

Namun di masa depan, sejalan dengan kemajuan teknologi, kemungkinan akan ditemukan teknologi yang mampu membersihkan dan mendaurulang secara efisien sehingga recovery material hasil galian TPA layak secara ekonomi. 


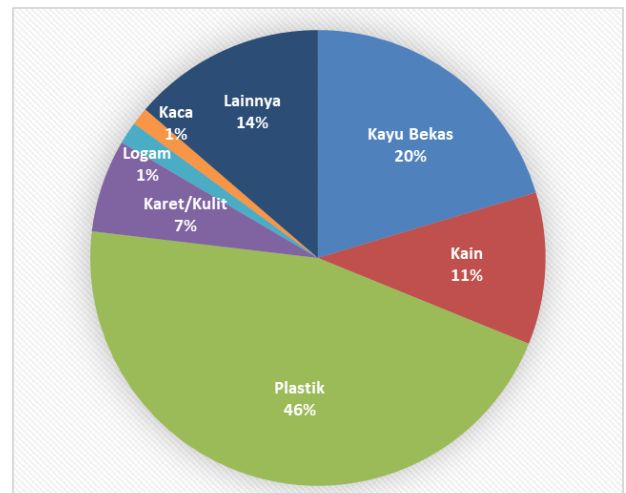

Gambar 3. Komposisi sampah TPA Bantargebang setelah komposnya disisihkan

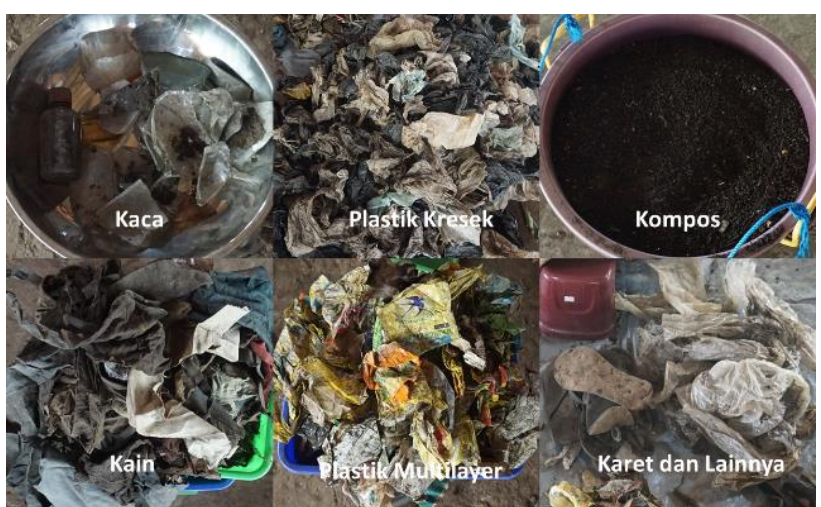

Gambar 4. Contoh beberapa jenis sampah hasil pemilahan TPA Bantargebang

\subsubsection{Material Lainnya}

Selain material yang berpotensi didaur ulang, terdapat pula material lain seperti batu, keramik, batu-bata dan sebagainya. Material tersebut berpotensi untuk digunakan sebagai material urugan lahan.

\subsection{Karakteristik Sampah Galian TPA dan Potensi Recovery Energi}

Sampah galian TPA potensial dimanfaatkan sebagai sumber energi atau RDF (refuse-derifed fuels) karena didominasi oleh material sampah yang dapat dibakar (combustible) dan memiliki nilai kalor yang relatif tinggi.

Material combustible dari TPA Sukawinatan dan TPA Bantargebang, komposisinya antara 55-58\% seperti terlihat pada Gambar 5, Gambar 6, dan Gambar 7. Sebagian besar sampah combustible adalah material plastik (32-43\%). Material combustible lainnya adalah combustible non-plastik seperti kayu, kain, karet, dan kulit (13-26\%).

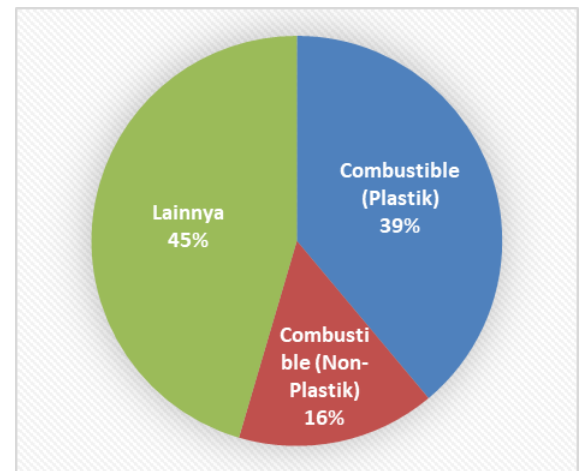

Gambar 5. Komposisi sampah dari lokasi 1 TPA Sukawinatan

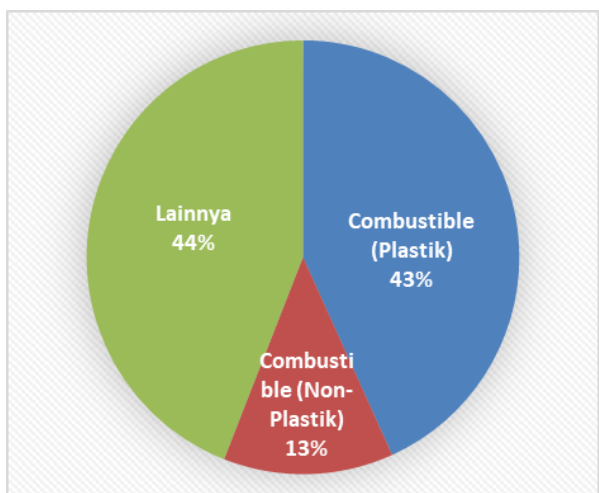

Gambar 6. Komposisi sampah dari lokasi 2 TPA Sukawinatan

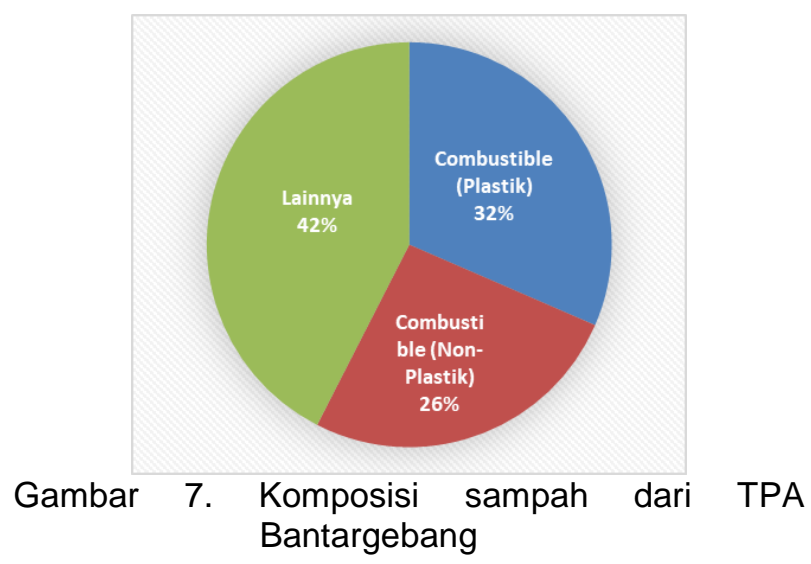

Ditinjau dari nilai kalornya (lower heating value), sampah combustible memiliki nilai kalor di atas $1700 \mathrm{kkal} / \mathrm{kg}$ atau di atas $7 \mathrm{MJ} / \mathrm{kg}$, dengan kadar air yang relatif beragam. Nilai kalor sampah galian dari TPA Sukawinatan antara 2.315 hingga 3.730 $\mathrm{kkal} / \mathrm{kg}(9,69$ - 15,61 MJ/kg) dengan kadar air 52,87-65,93\%; sedangkan dari TPA Bantargebang adalah $1.747 \mathrm{kkal} / \mathrm{kg}(7,31 \mathrm{MJ} / \mathrm{kg})$ dengan kadar air $31,8 \%$. Hal tersebut dapat dilihat pada Tabel 2 dan Tabel 
Tabel 2. Hasil analisis proksimat sampah galian TPA Sukawinatan

\begin{tabular}{|c|c|c|c|c|}
\hline \multirow[b]{2}{*}{ Parameter } & \multirow[b]{2}{*}{$\begin{array}{c}\text { Sebelum } \\
\text { Penjemuran }\end{array}$} & \multicolumn{3}{|c|}{ Setelah Penjemuran } \\
\hline & & $\begin{array}{c}\text { Combustible } \\
\text { (Plastik) }\end{array}$ & $\begin{array}{c}\text { Combustible (Non- } \\
\text { Plastik) }\end{array}$ & Lainnya \\
\hline \multicolumn{5}{|l|}{ Lokasi 1} \\
\hline Kadar Air (\%) & 69,23 & 52,87 & 65,63 & 50,67 \\
\hline Kadar Abu (\%) & 61,80 & 56,74 & 32,17 & 68,75 \\
\hline Volatile Matter (\%) & 38,20 & 43,26 & 67,83 & 31,25 \\
\hline Nilai Kalor (kkal/kg) & - & $2.785,9$ & $3.730,9$ & - \\
\hline Nilai Kalor (MJ/kg) & - & 11,66 & 15,61 & 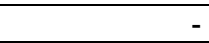 \\
\hline \multicolumn{5}{|l|}{ Lokasi 2} \\
\hline Kadar Air (\%) & 68,39 & 65,93 & 63,72 & 25,18 \\
\hline Kadar Abu (\%) & 70,51 & 38,26 & 27,91 & 56,64 \\
\hline Volatile Matter (\%) & 29,49 & 61,74 & 72,09 & 43,36 \\
\hline Nilai Kalor (kkal/kg) & - & $2.315,2$ & 2.565 & - \\
\hline Nilai Kalor (MJ/kg) & - & 9,69 & 10,73 & - \\
\hline
\end{tabular}

Tabel 3. Hasil analisa proksimat dan ultimat sampah galian TPA Bantargebang

\begin{tabular}{|l|c|}
\hline \multicolumn{1}{|c|}{ Parameter } & Nilai \\
\hline Analisis Proksimat \\
\hline Kadar Air (\%) & 31,8 \\
\hline Kadar Abu (\%) & 43,32 \\
\hline Volatile Matter (\%) & 30,39 \\
\hline Fixed carbon (\%) & 15,41 \\
\hline Nilai Kalor (kkal/kg) & 1.747 \\
\hline Nilai Kalor (MJ/kg) & 7,31 \\
\hline Analisis Ultimat & 49,215 \\
\hline $\mathrm{C}(\%)$ & 7,835 \\
\hline $\mathrm{H}(\%)$ & 30,550 \\
\hline $\mathrm{O}(\%)$ & 1,485 \\
\hline $\mathrm{N}(\%)$ & 0,260 \\
\hline $\mathrm{S}(\%)$ & 0,885 \\
\hline Klorin (\%) & \\
\hline \multicolumn{2}{|l|}{} \\
\end{tabular}

\subsubsection{Potensi Sampah Galian TPA untuk Bahan Bakar Insinerator PLTSa}

Potensi sampah combustible sebagai bahan bakar tergantung dari nilai kalornya. Menurut Laporan Pedoman Teknis World Bank tentang Insinerator Sampah Kota (1999), batasan teknis nilai kalor sampah untuk insinerator PLTSa (Pembangkit Listrik Tenaga Sampah) adalah ratarata nilai kalor minimal $7 \mathrm{MJ} / \mathrm{kg}$. Pengukuran nilai kalor terhadap material sampah dari hasil landfill mining di TPA Sukawinatan dan TPA Bantargebang menunjukkan angka di atas nilai rata-rata yang dipersyaratkan yaitu berturut turut $9,69-15,61 \mathrm{MJ} / \mathrm{kg}$ dan 7,31 MJ/kg.

Jika nilai kalor lebih rendah dari yang dipersyaratkan, sampah akan sulit terbakar, temperatur tungku insinerator akan turun, dan stabilitas pembakaran akan terganggu.

Nilai kalor sampah, secara teoritis tergantung dari karakteristik sampah yakni kadar air, volatile matter (zat terbang), dan abu. Apabila karakteristik sampah memiliki kadar air lebih kecil dari $50 \%$, kadar abu lebih kecil dari $40 \%$, dan volatile matter lebih besar dari $25 \%$, seperti yang tergambarkan dalam Segitiga Tanner, maka secara teoritis sampah berada pada posisi sebagai material yang dapat terbakar tanpa bahan bakar tambahan (11).

Namun pada kenyataannya, material combustible yang berasal dari TPA Sukawinatan dan TPA Bantargebang, walaupun dari aspek kadar air, kadar abu, dan volatile matter sebagian tidak memenuhi syarat, nilai kalornya masih di atas $7 \mathrm{MJ} / \mathrm{kg}$ sehingga masih dapat dibakar tanpa bahan bakar tambahan. Hal itu mungkin desebabkan oleh dominansi kandungan sampah plastik dan sampah lainnya yang memiliki nilai kalor tinggi.

Walaupun upaya untuk mengurangi kadar air telah dilakukan dengan cara menjemurnya selama 3 jam dan melakukan pengayakan, kadar air sampah combustible galian TPA Sukawinatan masih relatif tinggi yaitu antara 52,87-65,93\%. Kadar airnya masih lebih besar dari batasan teknis kadar air menurut World Bank (50\%). Sementara itu, kadar air sampah dari TPA Bantargebang masih sesuai dengan batasan teknis, yakni $31,8 \%$.

Sementara itu, kandungan volatile matter sampah galian dari TPA Bantargebang dan TPA Sukawinatan nilainya lebih besar dari batasan teknis kandungan volatile matter World Bank $(25 \%)$. Volatile matter merupakan senyawa yang mudah menguap yang akan mengalami penguraian termal dan menciptakan api. Komponen dasar zat terbang meliputi karbon, hidrogen, oksigen, nitrogen, dan sulfur (seperti pada Tabel 3).

Selanjutnya, sampah combustible galian TPA Sukawinatan setelah dijemur dan diayak memiliki kadar abu 27,91-56,74\%; sedangkan sampah galian TPA Bantargebang kadar abunya 43,32\%. Abu merupakan komponen yang tidak ikut bereaksi 
dalam reaksi oksidasi (pembakaran) sehingga tidak menyumbangkan nilai kalor pada sampah. Semakin tinggi kadar abu, umumnya nilai kalor akan menurun. Kadar abu sampah dari kedua TPA sebagian melebihi batasan teknis World Bank (lebih kecil dari 40\%).

Untuk melihat potensi sampah galian TPA sebagai bahan bakar di insinerator, Profesor Peter Quicker dari Aachen University - Jerman, telah melakukan uji pembakaran sampah galian TPA Pohlsche Heide (Jerman) di insinerator Bernburg. Hasil ujicoba menyimpulkan bahwa penggunaan sampah galian TPA untuk bahan bakar insinerator dapat dengan mudah dioperasikan dan produksi uap panasnya stabil. Hanya saja, dibandingkan dengan pembakaran sampah segar, pembakaran sampah galian TPA meningkatkan kandungan $\mathrm{HCl}$ pada gas buangnya, yakni 2 sampai 3 kalinya. Konsekuensinya, penggunaan sodium bicarbonate untuk menetralkannya meningkat 2 sampai 3 kalinya juga ${ }^{(12)}$.

Selaras dengan tingginya kadar abu dari sampah galian TPA, penggunaannya dalam insinerator diperkirakan akan berakibat pada meningkatnya produksi abu baik fly ash (abu terbang) maupun bottom ash (abu dasar). Hal ini perlu diperhatikan karena penanganan abunya juga akan semakin meningkat.
Dari uraian di atas dapat ditarik kesimpulan bahwa sampah galian TPA layak untuk dijadikan sebagai bahan bakar insinerator PLTSa dengan tetap memperhatikan beberapa hal seperti perlunya proses pengurangan kadar air, proses pengayakan dan proses pemilahan material sampah. Namun demikian, tingginya produksi abu harus mendapatkan perhatian karena akan berakibat pada semakin besarnya kapasitas penanganan abu yang diperlukan.

\subsubsection{Potensi Sampah Galian TPA untuk Bahan Bakar Industri Semen}

Selain untuk bahan bakar insinerator PLTSa, material combustible dari galian TPA berpotensi untuk ko-insinerasi pada industri semen untuk dimanfaatkan energinya. Namun berdasarkan Pedoman Spesifikasi Teknis RDF untuk Industri Semen (2017), karakteristik sampah hasil galian TPA Sukawinatan dan TPA Bantargebang masih belum memenuhi syarat sebagai RDF pada beberapa kriteria seperti nilai kalor, ukuran partikel, dan kadar abu.

Menurut Pedoman tersebut, standar RDF untuk cement kiln pada nilai kalor, ukuran partikel, kandungan klorin $(\mathrm{Cl})$, dan kadar abu secara berturut-turut adalah 20-25 MJ/kg; <10-30 mm; $<1,0-0,8 \%$; dan $<10 \%$ seperti yang dapat dilihat pada Tabel 4.

Tabel 4. Standar RDF dan karakteristik sampah galian TPA Sukawinatan dan TPA Bantargebang

\begin{tabular}{|l|c|c|c|}
\hline \multirow{2}{*}{ Parameter } & \multirow{2}{*}{$\begin{array}{c}\text { Standar RDF untuk } \\
\text { Cement Kiln* }\end{array}$} & \multicolumn{2}{c|}{ Karakteristik Sampah Galian } \\
\cline { 3 - 4 } & $4,778-5.973$ & TPA Sukawinatan & TPA Bantargebang \\
\hline Nilai Kalor (kkal/kg) & $20-25$ & $2.315-3,730$ & 1.747 \\
atau (MJ/kg) & $<10-30$ & $9,69-15,61$ & 7,31 \\
\hline Ukuran prtikel (mm) & $<1,0-0,8$ & Sebagian di atas $30 \mathrm{~mm}$ & Sebagian di atas $30 \mathrm{~mm}$ \\
\hline Kadar Klorin (\%) & $<10$ & Tidak dianalisa & 0,885 \\
\hline Kadar Abu (\%) & $61,80-70,51$ & 43,32 \\
\hline
\end{tabular}

Keterangan *: Berdasarkan Pedoman Spesifikasi Teknis RDF (2017)(13)

Nilai kalor material combustible dari galian TPA Sukawinatan dan TPA Bantargebang jauh di bawah standar yaitu antara $7,31-15,61 \mathrm{MJ} / \mathrm{kg}$ $(1.747-3.730 \mathrm{kkal} / \mathrm{kg})$. Kualitas nilai kalor tersebut kemungkinan disebabkan oleh kotornya material dan tingginya kadar air.

Untuk mengurangi material pengotor yang menempel pada sampah combustible hasil galian TPA, diperlukan proses penanganan yang meliputi pengeringan, pencacahan, pegayakan dan dilanjutkan dengan teknik pembersihan yang efektif(10). Bersihnya sampah combustible dari material pengotor, juga akan mengurangi tingginya kandungan abu pada material combustible dari
TPA Sukawinatan dan Bantargebang yang nilainya antara $43,32-70,51 \%$.

Ukuran partikel material combustible dari TPA Sukawinatan dan Bantargebang juga beragam dan sebagian berukuran di atas $30 \mathrm{~mm}$. Untuk memperkecil ukuran agar sesuai standar dapat dilakukan proses pencacahan. Proses pencacahan, selain dapat memperkecil ukuran material juga dapat mengurangi kadar air, meningkatkan nilai kalor dan membantu membersihkannya dari material pengotor.

Penelitian Lopes et al. (2017) terhadap sampah galian TPA dengan cara dicacah terlebih dahulu hingga fraksinya berukuran 10-40 cm, menghasilkan nilai kalor yang tinggi yaitu 25,01 - 
$32,56 \mathrm{MJ} / \mathrm{kg}(5.975-7.780 \mathrm{kkal} / \mathrm{kg})$ dengan kelembapan yang rendah yaitu antara $17-20 \%{ }^{(7)}$. Sementara itu, Zhou et al. (2014) menyebutkan sampah combustible plastik dari galian TPA di Tiongkok bagian tengah memiliki nilai kalor sebesar 43,18 MJ/kg (10.317 $\mathrm{kKal} / \mathrm{kg})$ dengan kadar air $19,9 \%{ }^{(10)}$.

Terhadap standar kandungan klorin $(\mathrm{Cl})$, kandungan klorin dalam sampah galian TPA Bantargebang masih dalam ambang batas yaitu $0,885 \%$. Klorin tidak diinginkan dalam RDF karena menyebabkan korosi.

Potensi RDF sampah galian TPA sebagai sumber energi di industri semen juga dilakukan oleh Profesor Peter Quicker, seperti halnya uji yang dilakukannya terhadap insinerator. Hasil ujicoba menyimpulkan bahwa penggunaan RDF sampah galian TPA Pohlsche Heide untuk industri semen tidak mungkin atau tidak layak karena beberapa hal, yakni: menghasilkan emisi klorin dalam kadar yang tinggi $(2,45 \%)$; kandungan logam berat di atas ambang batas; masalah berupa kecenderungan penggumpalan dan terjadinya penyumbatan pada sistem rotary valve; serta perlunya proses drying(12).

Walaupun saat ini dinyatakan tidak layak, penggunaan RDF galian sampah TPA sebagai bahan bakar cement kiln di masa depan masih terbuka kemungkinannya sejalan dengan perkembangan teknologi di masa depan baik itu teknologi pembuatan RDF maupun sistem pembakaran cement kiln dan kontrol polusi udaranya.

\subsection{Potensi Mendapatkan Lahan Baru}

TPA Sukawinatan dan TPA Bantargebang memiliki kondisi yang serupa yaitu kapasitasnya hampir penuh. Sejalan dengan semakin menyempitnya lahan di wilayah perkotaan, untuk mencari lokasi baru TPA demikian sulitnya. Namun demikian, untuk mendapatkan lahan TPA baru, dapat diupayakan dengan melakukan upaya landfill mining terhadap bagian TPA yang sudah ditutup.

Berdasarkan hasil pengamatan terlihat bahwa lokasi pengambilan sampel merupakan bagian TPA yang sudah relatif aman untuk dilakukan penambangan. Sampahnya sudah relatif stabil, dan produksi gasnya secara visual dan pembauan (pada saat penggalian) sudah tidak aktif lagi.

Namun demikian, sebelum melakukan landfill mining perlu direncanakan secara matang manajemen material output galian sampahnya. Material seperti kompos, material recyclable (yang potensial didaur ulang), material combustible, dan material lainnya perlu jelas penanganannya. Penanganan yang intensif perlu dilakukan sebelum memanfaatkan material tersebut di industri daur ulang dan dimanfaatkan energinya pada industri semen dan insinerator PLTSa. Penanganan yang intensif dapat berupa pencacahan (crushing), pemisahan berbagai ukuran fraksi (fractioning), pemisahan logam, dan pengeringan (drying) ${ }^{(12)}$.

\section{KESIMPULAN}

Berdasarkan hasil dan pembahasan, dapat ditarik beberapa kesimpulan sebagai berikut:

1. Sampah galian TPA didominasi oleh material kompos $(31-47 \%)$ dan material combustible plastik (32-43\%). serta combustible nonplastik (13-26\%).

2. Material seperti kompos dari sampah galian TPA jumlahnya relatif besar dan memiliki potensi sebagai pengganti soil cover TPA dan sebagai material pembenah tanah (soil conditioner).

3. Sampah galian TPA mengandung beberapa material yang berpotensi didaur ulang seperti sampah plastik. Namun kondisinya kotor dan masih bercampur sehingga perlu kegiatan lanjutan sebelum didaur ulang seperti kegiatan pemilahan dan pembersihan yang intensif.

4. Sampah galianTPA potensial dimanfaatkan sebagai sumber energi atau RDF (refusederifed fuels) karena didominasi oleh material sampah yang dapat dibakar (combustible) dan memiliki nilai kalor yang relatif tinggi $(7,31-15,61$ $\mathrm{MJ} / \mathrm{kg}$ ).

5. Sampah galian TPA berpotensi dan layak digunakan sebagai bahan bakar insinerator PLTSa. Namun dalam penerapannya masih memerlukan pre-treatment seperti pengeringan, pencacahan, pengayakan, dan pemilahan.

6. Sampah galian TPA berpotensi digunakan sebagai bahan bakar di industri semen. Namun saat ini pemanfaatannya masih menghadapi beberapa kendala seperti tingginya kandungan klorin dan kadar air.

\section{PERSANTUNAN}

Proses pengambilan sampel sampah di TPA Sukawinatan (Palembang) dan TPA Bantargebang (Bekasi) memerlukan bantuan tenaga kerja, alat berat dan peralatan pemilah sampah. Terimakasih disampaikan kepada Dinas Lingkungan Hidup (DLH) Kota Palembang dan DKI Jakarta yang telah membantu menyediakan sarana tersebut.

\section{DAFTAR PUSTAKA}

1. Hogland, W. (2011). Landfill Mining/Mining pa deponi. Program for Temamøte Grunnforurensning-spredning, utlekking og 
opprydding. Miljoringen nettverk for forurenset grunn og sedimenter, 2 Oktober 2011.

2. Prechthai, T., Padmasri, M., dan . Visvanathan, C. (2008). Quality Assessment of Mined MSW from an Open Dumpsite for Recycling Potential. Resources, Conservation and Recycling, 53, (1), 70 - 78, 2008.

3. Van der Zee, D.J., Achterkamp, M.C., dan de Visser, B.J., (2004). Assessing the Market Opportunities of Landfill Mining. Waste Management, 24, (8), 795-804, 2004.

4. Mathlener, R.A. (1999). Proceedings Sardinia 99, Seventh International Waste Management and Landfill Symposium. Padova, Italy: CISA Publishers, 1999, pp. 251-260.

5. Van Passel, S., De Gheldere, S., Dubois, M., Eyckmans, J., Vdan an Acker, K. (2010). Exploring the Socio-Economics of Enhanced Landfill Mining. $1^{\text {st }}$ International Symposium on Enhanced Landfill Mining, HouthalenHelchteren, 4 - 6 Oktober 2010.

6. Jones, P.T., Geysen, D., Rossy, A. Bienge, K. (2011). Enhanced landfill mining (ELFM) and Enhanced Waste Management (EWM): essential components for the transition to Sustainable Materials Management (SMM).https://www.researchgate.net/publicati on/228572171

7. Lopez, G.C., Clausen, A., dan Pretz, T. (2017). Landfill Mining: A Case Study on Sampling, Processing and Characterization of Excavated Waste From An Austrian Landfill. Sixteenth International Waste Management
And Landfill Symposium, Sardinia, 2 - 6 October 2017.

8. Frandegard, P., Krook, J., Svensson, N., dan Eklund, M. (2013). Resource and Climate Implications of Landfill Mining A Case Study of Sweden. Journal of Industrial Ecology, (17), 5, 742-755, 2013.

9. Pastre, G., Griffiths, Z., Val, J., Tasiu, A.M., Camachodominguez, E.V., Wagland, S., dan Coulon, F. (2017). A Decision Support Tool for Enhanced Landfill Mining. Proceedings Sardinia 2017/Sixteenth International Waste Management and Landfill Symposium, 2 - 6 October 2017.

10. Zhou, C., Fang, W., Xu, W., Cao, A., dan Wang, R. (2014). Characteristics and the Recovery Potential of Plastic Wastes Obtained from Landfill Mining. Journal of Cleaner Production (80), 80-86, 2014.

11. World Bank. (1999). Technical Guidance Report Municipal Solid Waste Incineration. The International Bank for Reconstruction and Development, World Bank, Washington, D.C.

12. Quicker, P. (2016). Landfill Mining: An Option to Trigger Resources? 8thCEWEP Waste-toEnergy Congress 2016, Circular Economy Meets Energy Union, Rotterdam, 16-17 Juni 2016.

13. Pedoman Spesifikasi Teknis Refuse Derived Fuel (RDF) sebagai Alternatif Bahan Bakar di Industri Semen. (2017). Pusat Penelitian dan Pengembangan Industri Hijau dan Lingkungan Hidup, Badan Penelitian dan Pengembangan Industri, Kementerian Perindustrian. 